
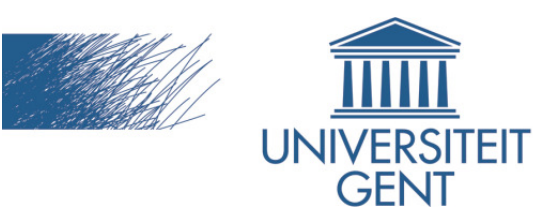

biblio.ugent.be

The UGent Institutional Repository is the electronic archiving and dissemination platform for all UGent research publications. Ghent University has implemented a mandate stipulating that all academic publications of UGent researchers should be deposited and archived in this repository. Except for items where current copyright restrictions apply, these papers are available in Open Access.

This item is the archived peer-reviewed author-version of:

Asylum Legislation and Asylum Applications: A Geographical Analysis of Belgian Asylum Policy by Country of Origin (1992-2003).

Vanheule, D. \& Witlox, F.

In: International Migration, 48(1), 129-147, 2010.

10.1111/j.1468-2435.2009.00555.x

To refer to or to cite this work, please use the citation to the published version:

Vanheule, D. \& Witlox, F. (2010). Asylum Legislation and Asylum Applications: A Geographical Analysis of Belgian Asylum Policy by Country of Origin (1992-2003). International Migration 48(1), 129-147. 10.1111/j.1468-2435.2009.00555.x 


\title{
Asylum Legislation and Asylum Applications: A Geographical Analysis of Belgian Asylum Policy by Country of Origin (1992-2003)
}

\author{
Dirk Vanheule ${ }^{*}$ and Frank Witlox ${ }^{* *}$ \\ ${ }^{*}$ Faculty of Law, University of Antwerp, Antwerpen, Belgium. \\ ** Department of Geography, Ghent University, Gent, Belgium.
}

\begin{abstract}
In many European countries a traditional policy and legal response to an undesirable increase of asylum applications has been the change of asylum law and procedures. By making it more difficult to obtain asylum and refugee status, the attractiveness as a possible country of asylum is believed to diminish. In the period from 1992 to 2003 three major revisions of the Belgian asylum procedure were enacted. When speaking in absolute figures these changes resulted in a certain decrease in the number of asylum applications filed. However, upon a closer examination of the number of asylum applications per country of origin, the effects appeared to be quite differential. Hence, factors other than geographical ones, such as the location of the country of origin or distance, must be decisive for the effect of a change in legislation on the number of asylum claimants coming from one particular country. Nevertheless, it has been possible to distinguish seven clusters of countries of origin where similar developments in patterns of asylum applications and shifts therein, depending on changes in asylum law, can be seen.
\end{abstract}

\section{INTRODUCTION}

During the last 15 years, the Belgian legislator has enacted various amendments to the asylum legislation and procedure, seeking among other things to limit what is regarded as a problematic increase in the number of applications for asylum. This seemed necessary because between 80 per cent and 90 per cent of asylum applications ultimately failed to lead to recognition of refugee status. Speeding up the asylum procedure by limiting the number of possible appeals, concentrating the power of decision making, and introducing additional grounds for the inadmissibility of an application have all been introduced in order to shorten the temporary stay of asylum seekers in Belgium, and thus to reduce the attractiveness of this status for people who are not refugees according to the terms of the Refugee Convention. ${ }^{1}$

This contribution investigates whether and to what extent the amendments to the asylum legislation have brought about a significant change in the number of applications for asylum. This study considers not only on the total number of asylum applications, but also the patterns of change in numbers according to the group or nationality of the persons requesting asylum in Belgium. By "asylum applications," or - to use a term closer to the language of the Belgian legislation - " requests for recognition of refugee status," we mean applications for recognition of refugee status as defined in Title II, chapter 2 of the Aliens Act of 15 December $1980 .^{2}$ 
In this paper we will present in turn: the collection of data and associated problems, a brief outline of the development of Belgian asylum law, the method developed in order to link the data on the number of asylum applications with the legislative amendments, an enquiry into whether each change in the law has had the same effect, and finally, a synthesis of the most significant findings.

\section{DATA COLLECTION}

\section{The relevant authorities}

The period covered by this research is a limited one. One could go back to 1980, a significant year since it was on 15 December of that year that the Aliens Act was adopted. This law contains, in Title II chapter 2, the criteria that govern the procedure still in use today in the recognition of refugee status.

For the period from 1980 until today, two different institutions have collected and stored the data relating to the number of asylum seekers. From 1980 to 1988, when the jurisdiction for making decisions regarding recognition was transferred to the Brussels representative of the United Nations High Commissioner for Refugees, this was done by the Immigration Service (Dienst Vreemdelingenzaken, Office des étrangers). In 1988 the (Belgian) Commissioner-General for Refugees and Stateless Persons (CGVS) obtained the authority for recognizing refugee status and in this capacity took charge also of the systematic collection of data on applications for recognition. One of the consequences of this move was that the data for the entire period between 1980 and 2003 have not been recorded in a uniform manner or, at any rate, are no longer to be found in such a form. The Immigration Service has only kept annual data according to nationality for the years 1980 to 1988 . The CGVS holds the data only from 1988 onwards. With regards to the latter, moreover, a distinction needs to be made: between 1988 and 1992 the data were recorded on an annual basis only, whereas from 1992 on the data by nationality were kept on a monthly basis.

Since only the CGVS could make the necessary data available and since we needed more precise figures for this research than what the annual data provide, the period that this research covers has necessarily been limited to that between January 1992 and December 2003 inclusively. The consequences of legislative amendments for 1981 to 1992 could not be investigated.

Problems with the data

The quality of the data is not easy to verify. The monthly totals were only checked at the end of each year, at which time it was indicated whether any correction was necessary. Apart from a few exceptional and thus insignificant cases, no correction was necessary.

Nevertheless, a few observations need to be made, especially regarding the linking or splitting of the data as a result of the union or separation of countries. Two significant examples of this are Zaïre/Democratic Republic of Congo and the Soviet Union/Commonwealth of Independent States (CIS). After the change in name from Zaire to the Democratic Republic of Congo, the data show that for six months the number of asylum applications from that country fell from around 
100 per month to zero, after which time it rose again to around 100 . For the same period, the number of asylum applications from Congo Brazzaville grew enormously, from around five per month to about 100, thereafter falling back to a much lower number. We can thus assume in this case that the fact that there were all of a sudden two Congos led to confusion, and that the data were incorrectly recorded. This can clearly be seen in the following graphs (Figures 1 and 2):

\section{$<$ Insert Figures 1 and 2 here $>$}

The second case has to do with the former Soviet Union, which split up into the 15 states of the CIS. Once the Soviet Union had officially split into 15 states, these were listed separately. Before that time, all data had been grouped together under the heading "total USSR." This had a twofold consequence. On the one hand, the figures dating from before 1998 indicate only a few or no asylum applications separately for each of these 15 countries. On the other hand, the applications listed under "total USSR" fall to zero after January 1998. It is impossible to combine the data for the states that after 1998 belong to the federation with the figures prior to 1998 because the former do not indicate which countries were included in the group "total USSR" and because we do not know the exact relationships between the different countries.

One consequence of this situation is that the numbers of asylum applications from certain countries in certain periods are overestimated, while for others they are underestimated. We must also take this fact into account in the further analysis of the data; otherwise it might lead to incorrect or misleading conclusions. In our research we have decided to compensate in part for the error with regard to Zaïre/Democratic Republic of Congo by taking the figures from the column for Congo Brazzaville and including them in the calculation for the Democratic Republic of Congo. These data were not omitted, however, from the calculation for Congo Brazzaville because they represent the sum of both countries, and thus also include the asylum seekers from Congo Brazzaville. It does mean that the figures represent an overestimation for Congo Brazzaville and result in double counting for this period.

\section{OVERVIEW OF THE LEGISLATIVE AMENDMENTS}

For an asylum "host country" such as Belgium, legislation is among the most important instruments for influencing the influx of asylum seekers who try to have their refugee status recognized here. An amendment in the legislation of a host country that makes the country less attractive for asylum claimants is an easier way to (try to) limit the number of asylum seekers than attempting to reduce or resolve the various local causes that lead people to migrate, including via development aid.

In the period covered by this research (1992-2003), three major legislative amendments must be considered: the changes to the Aliens Act in May 1993 and July 1996, and the amendment of the Public Centres of Social Welfare Act in January 2001. ${ }^{3}$ These amendments speed up the procedure, in part by extending the grounds on which a request for recognition may be declared inadmissible, broadening the measures limiting applicants' freedom, and restricting the financial support they may receive while in the country (see Bernard et al., 1998 ; Bossuyt et al., 1990; Carlier, 1989; Declercq, 1987; Denys, 1989; Foblets and Parmentier, 1993; Saroléa, 1998 ; Vanheule, 1990). 
Hence the places where an asylum seeker could submit a request for recognition was limited by the amendment of 6 May $1993^{4}$ to the authorities responsible for border control, the officials of the Immigration Service, or the director of the penitentiary institution in the case of detention. A second request for recognition can no longer be submitted if the asylum seeker him/herself does not bring new evidence forward. The grounds for inadmissibility have been extended. Further, certain asylum seekers can be assigned an administrative place of residence, for instance, a social service or reception centre that takes charge of providing support to the asylum seeker.

The amendments of July $1996^{5}$ reduce the periods within which a request for recognition can be submitted. As a result of the Schengen Agreement, Belgium must first inquire as to whether it is indeed responsible for dealing with the asylum application based on the criteria defined in the Schengen Convention (and later the Dublin Convention). ${ }^{6}$ The duration of detention was unlimited, but later, in 1998, it was limited to a maximum of eight months. ${ }^{7}$ Moreover, each asylum seeker is assigned to a reception centre where he or she has a right to bed and board as well as medical care. If he should move elsewhere, he loses the right to this support. The amendments of 1996 came into force over a series of dates between October 1996 and January 1997.

In 2001 a new and even more radical change to the Aliens Act and, in particular, to the recognition procedure was announced. The proposed amendment to the Aliens Act specified among others that the responsibilities of the Immigration Service, the CGVS, and the Permanent Refugee Appeals Commission would be redistributed among two new asylum authorities: the Federal Asylum Administration (FAA) and the Administrative Court for Asylum (ARA). The principle of "safe country of origin" was to be introduced, and a list was drawn up of countries considered safe and from which refugee candidates would therefore have far less chance of receiving recognition as refugees. ${ }^{8}$ The proposal never became law, because in the course of 2001 the influx of refugee candidates and the resulting overload on the existing recognition procedure came to an end. One of the most important measures of the "Purple-Green" coalition government (a coalition of liberals, social democrats, and greens) that seems to have contributed to this situation was the abolition of financial support for asylum claimants from social services. While the admissibility of their application is being considered, asylum seekers can, since January 2001, receive only material assistance from the reception centre to which they have been assigned. ${ }^{9}$ This change in social reception conditions for newly arrived asylum claimants was inspired by the legislator's intention to guarantee proper living and housing conditions and decent information on rights and obligations. Moreover, the settlement and material support in reception centres were seen as means to protect asylum seekers from abuses by landlords in private rental contracts and by malafide persons involved in human trafficking and claiming the social allowances received. ${ }^{10}$ Although this measure did not touch upon the asylum procedure as such, indirectly it has lead to a spectacular decrease in the number of asylum applications. As a result of this decrease in 2001, the government no longer saw the need for further reform in the asylum procedure or institutions.

More recently, two new sets of legislative amendments have been adopted. The first set of amendments of 15 September 2006 applies to various sections of the Aliens Act and covers a wide range of areas, such as family reunification and protection for victims of human 
trafficking. ${ }^{11}$ With regard to the asylum procedure, the amendments introduce subsidiary protection status, a status formerly unknown under Belgian law. The asylum procedure itself is simplified considerably through the almost exclusive attribution of the examination to a specialized agency (the CGVS) with possibility of appeal to a newly to be established Council for Aliens Litigation, thus limiting the role of the Minister of the Interior in the status determination process. A second set of amendments was adopted on 25 April 2007 and affects the residence status of EU citizens and long-term residents. ${ }^{12}$

Contrary to the prior amendments to the Aliens Act in the period 1987 to 2001, the more recent ones do not specifically aim at reducing the number of asylum applications. They transpose the various legislative initiatives that have been adopted at the EU level in the areas of migration and asylum under Title IV of the EC Treaty. The procedural changes must prevent new backlogs in the asylum procedure from appearing and while this may have an impact on the "attractiveness" to apply for asylum in Belgium, the deterrent effects of such a change seem not to have been the legislators' primary goal. The stabilization of the monthly number of asylum claims at a level manageable for the authorities may have influenced the decision not to tighten the procedure any further. The introduction of subsidiary protection status, as of 10 October 2006, could be a factor leading to an increase of asylum applications, as the legal basis for obtaining asylum becomes broader. At present, there are no indications however of such an increase, with the number of asylum applications remaining stable at approximately 1,000 per month.

From this brief overview of the measures introduced between 1992 and 2003, it is clear that the legislators have made access to and residence in the country through the asylum procedure more difficult and limited. The legislative amendments and interventions in the procedure were intended above all to reduce the number of asylum applications by persons who ultimately do not appear to be refugees according to the terms of the Refugee Convention.

\section{METHOD FOR LINKING THE DATA TO THE LEGISLATIVE AMENDMENTS}

In order to establish whether the amendments have succeeded in achieving this goal, we have worked out a method that links the monthly figures for the number of asylum applications to these amendments. This method rests upon two assumptions:

1. in general, we can assume that the goal of an amendment is (among others) to reduce the number of asylum applications;

2. a decrease in the number of asylum applications after the introduction of an amendment will show up as a decrease in monthly averages for the number of asylum applications during a certain period after the amendment.

The monthly average of asylum applications was calculated by country for a period before and after the amendment. When the average number is lower after the amendment than before, then we can assume that the amendment played a role in that decrease.

Specifically, calculations were made for 77 countries. The CGVS data cover a total of 149 countries or groups, but we decided to set a minimum threshold, so that countries from which 
fewer than 100 applications were submitted over the ten-year period were not included. This selection left us with 77 countries on which to base our study.

The period for which the averages were calculated is divided equally between the time before and after the amendments. In a certain number of cases this was not practicable, and another solution had to be found. Thus the averages were calculated from January 1992 to May 1993 (16 months) and from June 1993 to May 1995 (24 months) as regards the amendment of May 1993.

For the amendment of July 1996, we did look at a period of 24 months in each case when calculating the averages: from July 1994 to June 1996 and from August 1996 to July 1998. For the amendment of January 2001 as well, the averages were calculated over a period of two years before and two years after the amendment, that is, from January 1999 to December 2000 and from February 2001 to February 2003.

The time scale of two years was chosen because a legislative amendment will not lead to immediate results, but neither do its effects continue indeterminately. The figures are thus not too comprehensive, and the periods for which the averages are calculated do not overlap too much. Naturally one needs to be aware that the choice of this particular period can have a considerable influence on the results. The months in which the legislative amendments were promulgated are not included in calculating the averages. We decided to begin from the date of the promulgation, even when the amendment would only come into force at a later date. Thus the influence of communications concerning the amendments could be taken into consideration in our data.

This exercise can be repeated in 2008 and 2009 for the most recent legislative amendments adopted in September 2006 and April 2007 to examine their impact on the asylum applications.

Variations in the monthly average are indicated with "increase," "decrease," or "unchanged." "Unchanged" indicates a quasi-stable average (less than $0.5 \%$ difference in averages) before and after the amendment. For any variation greater than 0.5 per cent, the change is expressed as an increase or decrease, as the case may be. It is clear that in this regard as well, a different choice of minimum level of change would affect the results.

A tabulation of the variations calculated (Table 1) showing the number of cases in which there were increases, decreases, or stable numbers after an amendment, indicates the following:

\section{$<$ Insert Table 1 here $>$}

If we assume that the only goal of an amendment is to decrease the number of asylum applications, then on the basis of Table 1 we can affirm that the amendment of 2001 was the most successful one, for it was after this change that the largest decrease took place. This decrease continued also after the period looked at in this paper. In 2004 and 2005 the number of asylum claims stabilized at about 1,300 applications per month; in 2006 it further decreased to 1,000 applications per month.

The legislative amendments of 1993 and 1996 appear, by contrast, not to have achieved their goal. In 1993 an unexpectedly large number of countries even showed an increase. This was 
unexpected because the graph indicating the total number of asylum applications after 1993 in fact reveals a significant decrease.

This is clearly visible on the following graph (Figure 3):

$<$ Insert Figure 3 here $>$

Not all legislative amendments yield the same results. In the case of some, the decrease in number of asylum applications is more explicit than in others, and sometimes there is even an increase in the total number of applications.

An important question related to these figures is whether the various groups or nationalities always react in the same fashion to a given amendment. Might there be a difference between groups that are influenced by the legislation and groups for which this is not the case? In order to investigate this question, we looked at the combination of the three legislative amendments.

On the basis of a changed (increased or decreased) or an unchanged situation, various combinations were possible. In the "best" case, all three legislative amendments would have the same result, leading to a decrease in the number of applications. As Table 1 has already shown, there are not many cases in which this was so in practice.

If the number of possible combinations of "increase," "decrease," and "unchanged" are quite limited, a clearer picture emerges regarding the effect of an amendment for a particular country of origin. This means that if an amendment always has the same effect on the number of asylum applications from a certain country, then only three possible combinations can occur, namely: three increases, three decreases, or three unchanged situations.

If many other combinations appear as well, then we must conclude that an amendment to the immigration legislation does not always have the same effect on the number of applications for recognition of persons of a particular nationality. This may suggest that there are other factors besides amendments to the law that account for the number of asylum seekers from a particular country. This also means, therefore, that one cannot extrapolate from the effect of previous legislative amendments on a particular group in order to predict or guess the effect any future amendment might have.

As Table 2 indicates, there are quite a large number of combinations and the countries range quite widely across these combinations:

\section{<Insert Table 2 here>}

We can conclude from the above figures that it is not easy to reach an unambiguous judgment as to the success (in terms of the intended influence on the number of asylum applications) of the legislative amendments that have been introduced. It is clear that in addition to the amendment in question, many other factors play a role in determining the fluctuation in the number of asylum applications. If the amendments alone were responsible for the difference, then it could be that different groups react to them in different ways, and that this explains the differences between the increase, decrease, and stability as shown in Table 1. However, it would be quite illogical to think 
that different groups would continue to react in the same way over time, and this is certainly confirmed by the many different combinations that appear in Table 2 . The amendments may indeed have had an influence - although there is no way to infer how great that influence was and may thus be one factor accounting for the behaviour of the various groups in choosing to seek asylum in Belgium. Other factors also play a role and can often be of greater importance in determining the choice of Belgium as a country of destination.

This conclusion confirms, moreover, what Böcker and Havinga (1998) had earlier noted:

The asylum policy and reception of asylum seekers in the country of destination also does not appear to be a dominant factor in explaining the patterns of destination for asylum seekers... Some factors are generally not important but may nevertheless be very important for asylum seekers from a particular country of origin going to a particular country of destination at a particular time... In political discussions, asylum policy is typically perceived as an instrument to reduce the influx of asylum seekers. Our study has shown the impact of asylum policy to be rather limited in the long run. Restrictive measures produce a shift in the destinations of asylum movement. Even then, these shifts may only occur for specific groups of asylum seekers and be very temporary.

It is clear that other factors need to be examined in order to explain the number of asylum applications. First of all, the situation (political, economic, social) in the country of origin plays a crucial role. An example of this is the decline in the number of asylum applications after January 2001 that can be attributed to a decrease in the number of applications from (former) Yugoslavia, given the stabilization of that country after the intervention of the United Nations and new elections. The presence of "pioneers" (family or acquaintances who, deliberately or by chance, ended up in Belgium and requested asylum here) can also help explain the arrival of other people with the same nationality. One reason why these pioneers are present in that country may be the historical links (such as the colonial past of a particular source country) or other ties, such as business contacts, a similar cultural background, provision of development aid, and so forth, whereby the country of destination has gained "renown" in the country of origin. In addition, various "irrational factors" can play a role. Thus the bankruptcy of Belgium's national carrier Sabena with its African network, for instance, and the fact that there were temporarily no flights going from Brussels to Africa in 2001 may have affected the number of African asylum applications during that period. Furthermore, we should not forget that developments in Belgium cannot be seen in isolation from those in other countries. It can happen that there is a spectacular decrease in the number of asylum applications in Belgium, but that this decrease goes hand-inhand with an increase in other countries of the European Union, especially among Belgium's neighbours. There is an international dynamic that is often not taken into consideration when making policy. ${ }^{13}$

\section{IS IT POSSIBLE TO FORM GROUPINGS AMONG THE SOURCE COUNTRIES?}

Despite the diversity of factors that explain why an asylum seeker might "choose" Belgium as the country of destination, the question arises whether it might nonetheless be possible to group the countries of origin according to some common factors. On the basis of indexed numbers of 
asylum seekers, we can investigate whether there are countries that have followed similar patterns of development and that are in some way related to each other.

These index numbers were calculated per year, in relation to 1992 as the base year. Working with index numbers has the advantage that one can distinguish between absolute and relative change in the number of asylum seekers. Absolute differences cannot be compared, since they do not start from the same basis; using index numbers makes comparison possible. Thus 1992 was taken as the base year for each country, and the number of asylum applications from that country that year was fixed at 100 . For all other years, the percentage was calculated in relation to the base year, thus expressing the findings in terms of percentage change. Figures from two consecutive years cannot be expressed as a percentage change - this can only be done in relation to the base year. What can be established is whether a rise or a fall continues, speeds up or slows down in comparison to previous years. A comparison between the different countries can thus be shown on a graph of these index numbers by country, allowing one to determine whether they follow the same pattern.

By comparing the graphs by continent, on the basis of similar curves of index numbers we see a few clusters of countries emerge. Of these, we looked at whether these countries are geographically near each other. But the social background could also be examined. By this we mean whether they were, for instance, ever colonized by Belgium, have received significant development aid from Belgium, and so forth. In further studies it would also be possible to look at the effect of trade relations.

Proceeding in this fashion, seven groups of countries can be distinguished that have one principal characteristic in common: geographical proximity. It seems possible to divide the asylum seekers' countries of origin into clusters or groups of countries that have followed a similar developmental trajectory in "bringing in" asylum seekers, and these countries are generally near each other. The seven distinct groups are:

1. Ghana, Togo, Burkina Faso, Morocco, and the Democratic Republic of Congo. The presence in this group of Morocco and the Democratic Republic of Congo is surprising, as these countries lie geographically farther away from the others. Their presence in the group might be explicable by the fact that they are part of the group of African countries where Belgium is actively providing development aid.

2. Nigeria and Ivory Coast: this group may be regarded as having been formed by a "ripple effect" of the previous group. Both countries border on the previous group: Nigeria in the east and Ivory Coast in the west. It is interesting to note that this effect does not seem to have spread toward the north.

3. Bosnia, Croatia, Bulgaria, Hungary, FYROM, Rumania, Poland, and Turkey form a third group. These can, in spite of the presence of Poland, be seen as a "Balkan cluster." The FRY does not belong to this group, as its index numbers follow a unique trajectory.

4. Lithuania, Armenia, Georgia, Ukraine, and Russia make up a first Russian cluster.

5. The second Russian cluster includes Belarus, the states of the former USSR, and Latvia. The first and second Russian clusters can be seen in part as "ripple effects" of each other.

6. A sixth cluster is located in South Asia and includes Bangladesh, China (+ Hong Kong), Pakistan, Viet Nam, and to a lesser extent India. India had a different trajectory in the 
initial years, but by the end of our period coincides with that of the other countries in the cluster.

7. Finally, there is the Middle Eastern cluster that includes Iraq, Iran, Syria, Lebanon, and Jordan.

The other countries have their own particular dynamic and are more difficult to group under one category.

\section{CONCLUSIONS}

There is no simple answer to the question whether there is a link between the legislative amendments and the changing number of asylum applications. It is certain that the government of a country of asylum regards its own legislation as an important means of influencing the number of asylum applications.

Whether this in fact has a significant influence on the asylum seeker is for the moment far from clear. The average number of asylum applications does not always decrease after an amendment. The most "successful" amendment seems to have been that of 2001, as it was the one that led to the greatest decrease in the number of asylum applications, and also influenced the largest number of nationalities. However, that amendment was not an amendment of the immigration procedure per se but of the reception conditions in Belgium with an aim to ensure better and safer reception of newly arrived asylum claimants.

Nevertheless, legislative amendments are but one of the many factors that can account for the fluctuations in the number of asylum applications. Other factors include: the sudden escalation of a conflict in the country of origin, natural disasters, economic motives such as flight from poverty, and so forth. Reasons why these asylum seekers choose Belgium as their destination may be, for instance, the presence of family members here, information available about the country, and so on.

With respect to the question whether the source countries can be grouped in a logical manner, there are two possible answers. To some extent it is possible to do so, for on the basis of patterns in the index numbers we can distinguish seven different groups, with the most important common characteristic that of geographical proximity. But on the other hand, not all countries fit into one of these clusters. Geographic proximity is thus but one element, for if other factors are also taken into account (history, cooperation in development, trade relations, and so forth), the composition and interpretation of these groups can look quite different.

\section{Acknowledgements}

The authors thank Mr. K. Luxem (Federal Public Service of the Interior) and Messrs. D. Van den Bulck and F. Bienfait (Commissioner General for Refugees and Stateless Persons resp. Deputy Commissioner) for making the necessary data available. We also acknowledge the initial input made by L. De Muer (graduated Master student at Department of Geography, Ghent University) 
and are indebted to the editor and referees of International Migration for their comments and questions on an earlier draft of this paper.

\section{Notes}

1. Convention 28 July 1951 Relating to the Status of Refugees, 189 UNTS 150.

2. Wet 15 december 1980 betreffende de toegang tot het grondgebied, het verblijf, de vestiging en de verwijdering van vreemdelingen, Belgisch Staatsblad 31 December 1980 (Act of 15 December 1980 concerning access to the territory, residence, establishment, and removal of aliens; hereinafter: Aliens Act).

3. Organieke wet 8 juli 1976 betreffende de openbare centra voor maatschappelijk welzijn, Belgisch Staatsblad 5 August 1976, err. 26 November 1976 (Public Centres of Social Welfare Act 8 July 1976).

4. Act of 6 May 1993 amending the Act of 15 December 1980 concerning access to the territory, residence, establishment ,and removal of aliens, Belgisch Staatsblad 21 May 1993.

5. Act of 15 July 1996 amending the Act of 15 December 1980 concerning access to the territory, residence, establishment, and removal of aliens and of the Public Centres of Social Welfare Act of 8 July 1976, Belgisch Staatsblad 5 October 1996.

6. These conventions specify which states, party to the convention, are responsible for dealing with a request for recognition. In theory only one state is responsible, so that asylum seekers who try to obtain recognition in another state will be taken over or returned by the state that is responsible. The criteria for determining this responsibility include, among others, the granting of a residence permit or visa to the asylum claimant and the admission to the territory or the place where the person first arrived in the Schengen area.

7. Act of 9 March 1998 amending the Act of 15 December 1980 concerning access to the territory, residence, establishment, and removal of aliens, Belgisch Staatsblad 3 July 1998.

8. Regarding these plans, see Vanheule (2002).

9. Art. 57ter and 57ter, Public Centres of Social Welfare Act as amended by Art. 70 and 71, Act of 2 January 2001 concerning social, budgetary, and other measures, Belgisch Staatsblad 3 January 2001 (second edition).

10. Parl. Doc. Chamber of Representatives 2000-2001, 50-0950/001: 37-38.

11. Act of 15 September 2006 amending the Aliens Act of 15 December 1980, Belgisch Staatsblad 6 October 2006; Act of 15 September 2006 reforming the Council of State and creating a Council of Aliens Litigation, Belgisch Staatsblad 6 October 2006. See on this topic, Vanheule (2007).

12. Act of 25 April 2007 amending the Act of 15 December 1980 concerning access to the territory, residence, establishment, and removal of aliens, Belgisch Staatsblad 10 May 2007 (third edition)

13. On this topic see, among others, J. Wets (2002). 
Bernard, F., et al.

1998 "Vluchtelingen" (Refugees), in Migratie- en Migrantenrecht: Artikelsgewijze commentaar van de Vreemdelingenwet (Migration and Migrants' Law: An articleby-article commentary on the Aliens Act), Die Keure, Bruges.

Böcker, A.G.M., and T. Havinga

1998 Asylum Migration to the European Union: Patterns of Origin and Destination, Office for Official Publications of the European Communities, Luxemburg.

| Bossuyt, M., et al. (Eds)

Carlier, J.Y.

$19 \overline{9} 0$ La reconnaissance de la qualité de réfugié et l'octroi d'asile, Bruylant, Brussels.

1989 Droits des réfugiés, E. Story-Scientia, Brussels.

Declercq, L.

1987 "Wijzigingen aan de Vreemdelingenwet wat de vluchtelingen betreft"

(Amendments to the Aliens Act with regard to refugees), R.W.: 226.

Denys, L.

1989 Vreemdelingenrecht. Commentaar (Immigration Law: A Commentary), loose-leaf, U.G.A., Heule.

Foblets, M.C., and S. Parmentier (Eds)

1993 De Nieuwe Vluchtelingenwet. Commentaar op de wet van 6 mei 1993 (The new refugee law: commentary on the law of 6 May 1993), Mys \& Breesch, Ghent.

Saroléa, S

1998 Les droits des réfugiés, Ed. Jeunesse et Droit, Liège. Vanheule, D.

1990 Vluchtelingen. Een overzicht (Refugees: An Overview), Mys \& Breesch, Ghent.

2002 "Het recht op asiel en de asielprocedure in een nationaal en Europees perspectief" (The right to asylum in a national and European perspective), in M.C. Foblets, et al. (Eds.), Migratie- en Migrantenrecht: recente ontwikkelingen (Migration and migrants' law: recent developments), part II, Die Keure, Bruges: 123-227.

2007 "The qualification directive: a milestone in Belgian asylum law," in K. Zwaan (Ed.), The Qualification Directive: Central Themes, Problem Issues, and the Implementation in Selected Member States, Wolff, Nijmegen.

Wets, J.

2002 "De impact van de asiel- en migratiebeleid op grootschalige migratie en vluchtelingenstromen en vice versa" (The impact of asylum and migration policy on large-scale migration and refugee flows and vice versa), in M.C. Foblets, et al. (Eds), Migratie- en Migrantenrecht, part 7, Die Keure, Bruges: 229-247.

Formatted: Dutch (Belgium)

Comment [MH3]: Author: please provide author name.

Formatted: Dutch (Belgium)

Formatted: Dutch (Belgium)

Formatted: Dutch (Belgium)

Formatted: Dutch (Belgium) 
Tables and Figures

Number of asylum seekers from Congo Brazzaville

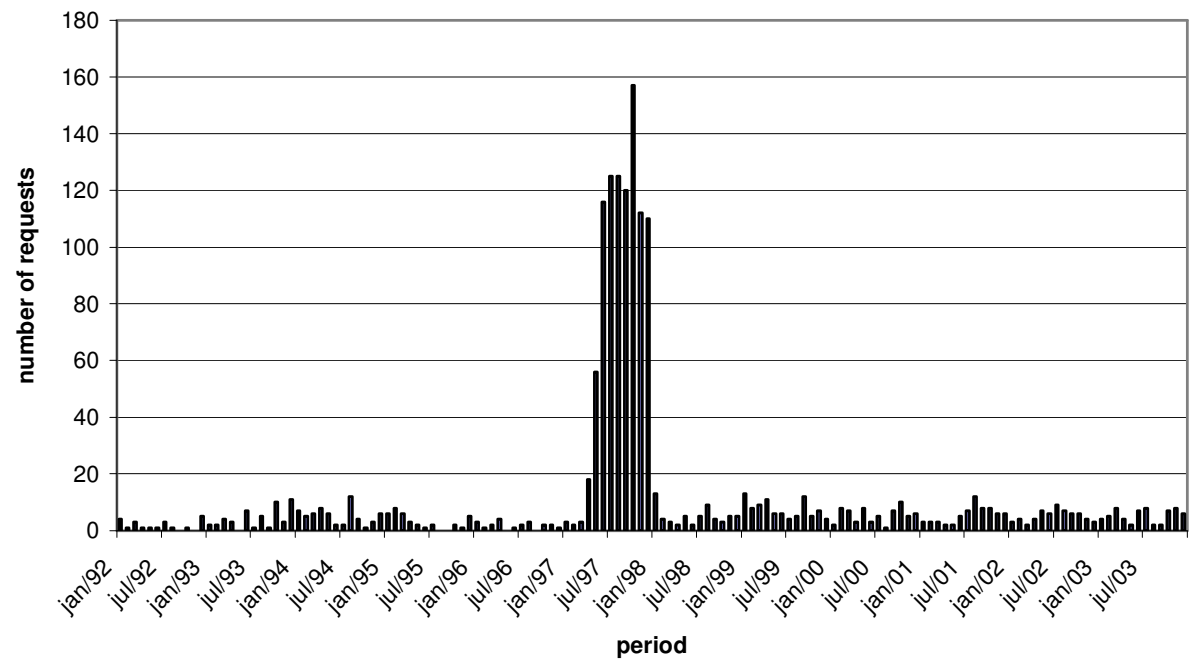

Figure 1: Number of asylum applications from Congo Brazzaville 1992-2003 
Figure 2

Number of asylum applications from the Democratic Republic of Congo, 1992-2003

Number of asylum seekers from the Democratic Republic of Congo (Zaïre)

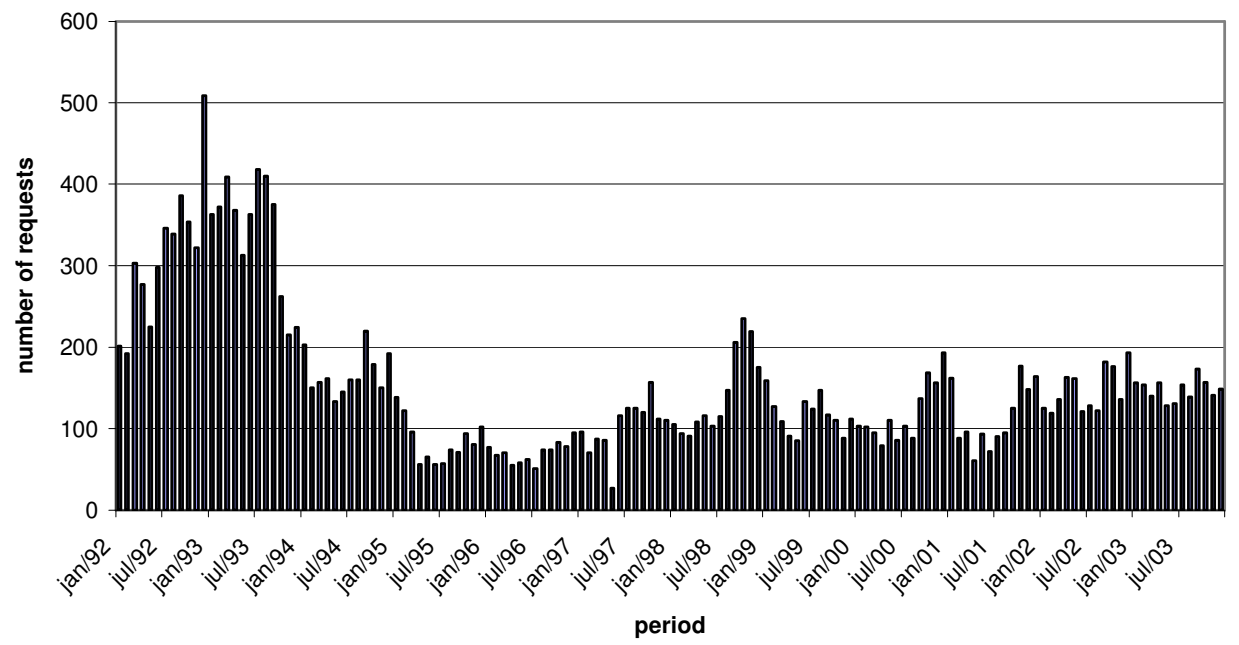


Figure 3

The total number of asylum applications in Belgium per month, 1992-2003

Change in the number of asylum requests in Belgium per month (1992-2003)

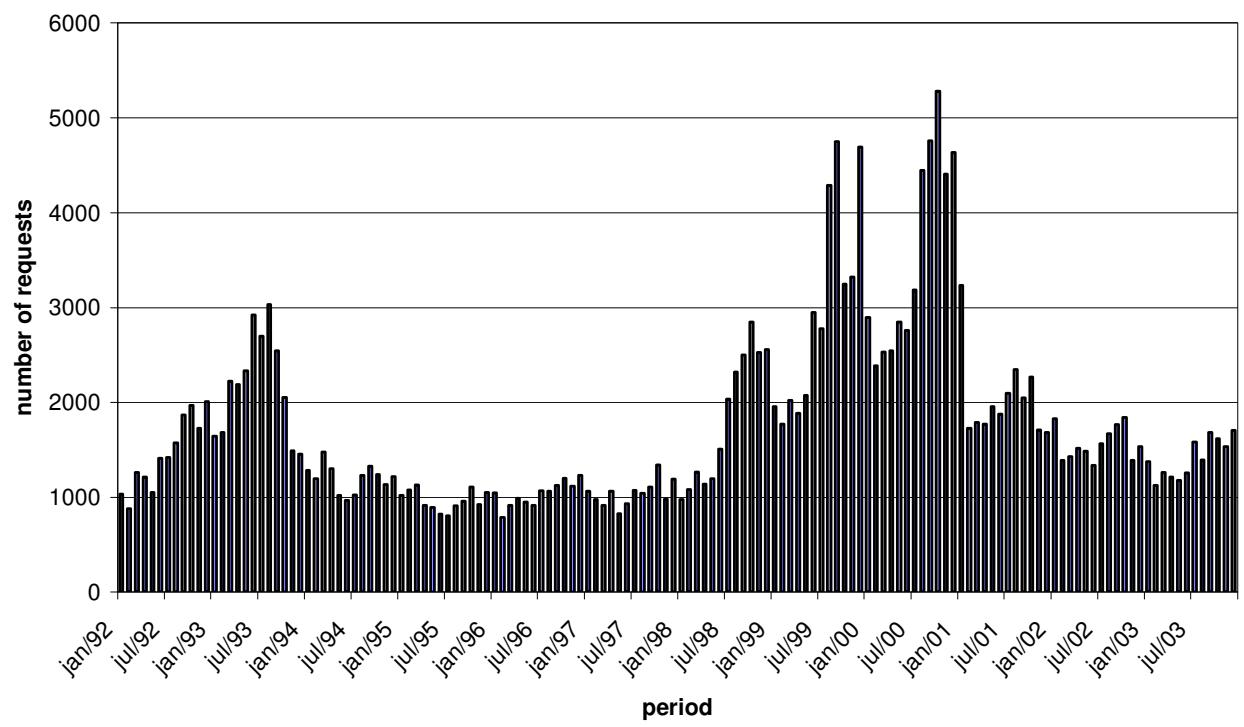


Table 1

Change is monthly number of asylum applications for a period before and a period after a legislative amendment

\begin{tabular}{|l|l|l|l|}
\hline & Increase & Decrease & Unchanged (stable) \\
\hline 1993 & 40 out of 77 & 23 out of 77 & 14 out of 77 \\
\hline 1996 & 34 out of 77 & 29 out of 77 & 14 out of 77 \\
\hline 2001 & 16 out of 77 & 46 out of 77 & 15 out of 77 \\
\hline
\end{tabular}


Table 2

The 77 countries studied, grouped according to the change in number of asylum applications after an amendment

\begin{tabular}{|c|c|}
\hline Combinations & Source Country \\
\hline Decrease '93, decrease '96, decrease '01 & Bosnia-Herzegovina, Croatia, Rumania \\
\hline Decrease '93, decrease '96, unchanged '01 & Ghana, Morocco, Nigeria, Peru \\
\hline Decrease '93, decrease ‘96, increase '01 & $\begin{array}{l}\text { Democratic Republic of Congo, Liberia, } \\
\text { Togo, Turkey }\end{array}$ \\
\hline Decrease '93, unchanged '96, decrease '01 & Chile \\
\hline Decrease '93, unchanged '96, unchanged '01 & Burkina Faso \\
\hline Decrease '93, unchanged '96, increase '01 & Hungary, Niger \\
\hline Decrease '93, increase '96, decrease '01 & $\begin{array}{l}\text { Belarus, India, Lebanon, Pakistan, Somalia, } \\
\text { Sri Lanka }\end{array}$ \\
\hline Decrease '93, increase '96, unchanged '01 & Viet Nam \\
\hline Decrease '93, increase '96, increase '01 & China (+ Hong Kong), Guinea Conakry \\
\hline Unchanged '93, decrease '96, decrease '01 & Ethiopia, Iran \\
\hline Unchanged '93, unchanged '96, decrease '01 & Kyrgyzstan, Mongolia, Myanmar, Uzbekistan \\
\hline Unchanged '93, unchanged '96, unchanged '01 & Jordan \\
\hline Unchanged '93, increase '96, decrease '01 & $\begin{array}{llll}\text { Djibouti, } & \text { Ecuador, Iraq, Kazakhstan, } \\
\text { Lithuania } & & \\
\end{array}$ \\
\hline Unchanged '93, increase '96, unchanged '01 & Kenya, Palestinian stateless persons \\
\hline Increase '93, decrease '96, decrease '01 & $\begin{array}{l}\text { Bangladesh, Bulgaria, Georgia, Ivory Coast, } \\
\text { Mauritania, Senegal, total USSR }\end{array}$ \\
\hline Increase '93, decrease '96, unchanged '01 & Cuba, Egypt, Gambia, Poland \\
\hline Increase '93, decrease '96, increase '01 & $\begin{array}{l}\text { Algeria, Angola, FYROM (Macedonia), } \\
\text { Sudan }\end{array}$ \\
\hline Increase '93, unchanged '96, decrease '01 & Latvia, Tajikistan \\
\hline Increase '93, unchanged '96, unchanged '01 & South Africa \\
\hline Increase '93, unchanged '96, increase '01 & Benin, Nepal + Tibet \\
\hline Increase '93, increase '96, decrease '01 & $\begin{array}{l}\text { Afghanistan, Albania, Armenia, Azerbaijan, } \\
\text { Bhutan, Burundi, Columbia, FRY (former } \\
\text { Yugoslavia), Congo Brazzaville, Moldavia, } \\
\text { Ukraine, Russia, Rwanda, Sierra Leone, } \\
\text { Slovakia, Czech Republic }\end{array}$ \\
\hline Increase '93, increase '96, unchanged '01 & Syria \\
\hline Increase '93, increase '96, increase '01 & Israel, Cameroon \\
\hline
\end{tabular}

